\title{
Study on the involvement of soluble guanylyl cyclase and its different isoforms in carbon monoxide and carbon monoxide releasing molecule-2 induced vasodilatation
}

\author{
Kelly Decaluwé ${ }^{* *}$, Bart Pauwels ${ }^{1}$, Sara Verpoest ${ }^{1}$, Robrecht Thoonen ${ }^{2,3}$, Emmanuel Buys $^{4}$, Peter Brouckaert ${ }^{2,3}$, \\ Johan Van de Voorde ${ }^{1}$
}

From 5th International Conference on cGMP: Generators, Effectors and Therapeutic Implications Halle, Germany. 24-26 June 2011

\section{Background}

Besides nitric oxide, carbon monoxide $(\mathrm{CO})$ also activates soluble guanylyl cyclase (sGC). $\mathrm{CO}$ as well as the CO-donor CORM-2 have been shown to possess vasodilatory properties. Whether these vasodilatory properties by $\mathrm{CO}$ can be attributed to sGC activation is still a matter of debate. The aim of this study was to examine the involvement of sGC and its different subunits in $\mathrm{CO}$ and CORM-2 induced vasodilatation within different vascular tissues.

\section{Materials and methods}

Isometric tension recordings were performed using mice isolated aortic rings, femoral artery ring segments as well as corpora cavernosa (CC). To be able to distinguish between the different sGC subunits we evaluated responses to saturated $\mathrm{CO}$ solutions and CORM-2 in both $\mathrm{sGCa}_{1}{ }^{-1-}$ and $\mathrm{sGC} \beta_{1}{ }^{\mathrm{KI} / \mathrm{KI}}$ mice and their wild-type controls.

\section{Results}

Saturated CO solution was unable to relax mice isolated blood vessels, whereas it induced concentrationdependent relaxations in mice CC. In CC of wild-type mice, the response to $\mathrm{CO}$ was completely inhibited by the sGC inhibitor ODQ. The involvement of sGC in the $\mathrm{CO}$-induced corporal relaxation was further confirmed by the loss of response to $\mathrm{CO}$ in $\mathrm{CC}$ isolated

\footnotetext{
* Correspondence: Kelly.decaluwe@ugent.be

'Department of Pharmacology, Ghent University, Ghent, Belgium

Full list of author information is available at the end of the article
}

from $\mathrm{sGC} \beta_{1}{ }^{\mathrm{KI} / \mathrm{KI}}$ mice. Moreover, the vasodilatory responses of $\mathrm{CO}$ in the corporal tissue of $\mathrm{sGCa}_{1}{ }^{-/ \text {- }}$ mice were strongly inhibited although not completely abolished. In contrast to CO, CORM-2 was able to relax all vascular tissues examined in the present study, although ODQ only partially blocked the response to CORM-2 in the aorta. Interestingly ODQ did not affect the CORM-2 induced relaxation in the femoral arteries and the $\mathrm{CC}$, indicating that sGC is not involved, which was confirmed using the transgenic mice.

\section{Conclusion}

This study clearly illustrates that the molecular mechanism of CORM-2 induced vasorelaxation differs from that of $\mathrm{CO}$ induced vasorelaxation. While the $\mathrm{CO}$ induced vasorelaxation depends on activation of sGC, primarily the sGCa $\beta_{1}$ heterodimer, the vasorelaxing properties of CORM-2 are only partially dependent or even completely independent upon sGC activation. The observation that $\mathrm{CO}$ is more effective in relaxing $\mathrm{CC}$ tissues than other cardiovascular tissues investigated in the present study suggests that the heme-oxygenase/CO pathway may present a potential new target for therapeutic approaches towards erectile dysfunction.

\footnotetext{
Author details

'Department of Pharmacology, Ghent University, Ghent, Belgium.

2Department for Molecular Biomedical Research, VIB, Ghent, Belgium.

${ }^{3}$ Department of Biomedical Biology, Ghent University, Ghent, Belgium.

${ }^{4}$ Anesthesia Center for Critical Care Research, Department of Anesthesia and
} 
Published: 1 August 2011

doi:10.1186/1471-2210-11-S1-P20

Cite this article as: Decaluwé et al:: Study on the involvement of soluble guanylyl cyclase and its different isoforms in carbon monoxide and carbon monoxide releasing molecule-2 induced vasodilatation. BMC

Pharmacology 2011 11(Suppl 1):P20.

Submit your next manuscript to BioMed Central and take full advantage of:

- Convenient online submission

- Thorough peer review

- No space constraints or color figure charges

- Immediate publication on acceptance

- Inclusion in PubMed, CAS, Scopus and Google Scholar

- Research which is freely available for redistribution

Submit your manuscript at www.biomedcentral.com/submit
() Biomed Central 